\title{
Juliano Garcia Pessanha
}

Como você pensa a relação entre o tempo literário e o tempo histórico?

A literatura está imersa no tempo histórico. Ela pode, entretanto, ultrapassar e transgredir essa filiação ao nomear a experiência histórica num gesto de interrupção profética ou no anúncio das possibilidades enterradas e dos povos ainda não nascidos. Nesses casos, há uma extrema fidelidade e penetração na época, possibilitadas por uma diferença e divergência radical.

\section{Quais procedimentos sua obra adota diante de} um mundo em que predominam a ação econômica e a espetacularização da arte?

Adotar procedimentos seria um gesto homólogo e pertencente ao mesmo tipo de racionalização que gerou ou é cúmplice do predomínio da ação econômica $e$ do ofuscamento reificado da arte-produto. Longe de qualquer procedimento técnico, que apenas ratifica o mesmo, confio na palavra haurida no território onde seremos livres. O homem é livre ali onde, dócil, se deixa arruinar pelas alteridades que o atravessam: o corpo, a morte, o nada, a vibração e a própria linguagem. Foi o recalque de tudo isso que possibilitou tanto a figura do "eu" quanto a do homem-produção. Existir e dizer a partir dessas figuras seria estar identificado com uma violência e uma alienação imensas.

(Quando se pensa e se diz a partir da interrupção e do lugar pressentido, nota-se que a própria noção de arte indica apenas que o homem não vive ainda à altura do poema.)

\section{Qual reflexão sua obra produz sobre a tradição literária brasileira?}

A literatura brasileira não tem o estranhamento em sua origem. Por isso, ela diz e rediz o mundo confirmando-o e mantendo o seu poder de atração. Sofre de um excesso de identificação com o instituído. É apenas quando se ama o abismo, a fenda e o real que se percebe que o universo e o homem não cabem no mundo; nesse caso, a literatura diz o mundo desdizendo-o, dizendo-o a partir do outro do mundo. Isso fica claro quando comparamos a literatura brasileira com a russa, por exemplo. Se tomarmos Gogol como um dos primeiros narradores russos, vemos que, enquanto ele estranhou o nariz (estranhamento diante da abstração e do social), nossos narradores queriam levar mais rapé para o mesmo nariz progredir e empinar.

Como explicar a diferença entre uma literatura que se assenta e se aninha no mundo, e outra que o estranha e o rói como uma traça?

Se tomo essas considerações - considerações hauridas naquilo que meu olhar carrega (um olhar não construído, mas reconhecido após muitos anos...) - como hipótese crítica, então seria necessário reler a literatura brasileira à luz deste olhar específico. De imediato destacaria a obra de Clarice Lispector pela potência do estranhamento e a de Jorge de Lima pelo pressentimento do espaço edênico, espaço da biografia do Homem.

\section{Como você pensa a forma literária?}

A forma literária nasce do modo como o corpo do escritor experimenta a época. No meu caso concreto, todo dizer está vinculado à experiência natal do encontro com o mundo técnico. Um corpo que não pôde florescer recua e se protege na negatividade. Habitando um mundo estranho, aguarda por um outro encontro, um encontro sem medida. É uma palavra de travessia do instituído. Uma forma literária entre o e-mail e a oração (entre a captura da informação e o pressentimento do poema).

Juliano Garcia Pessanha (1962) publicou Sabedoria do nunca (1999), Ignorância do sempre (2000), Certeza do agora (2002) e Instabilidade perpétua (2009), pela Ateliê Editorial. 